\section{Identification of Key Periods of Temperature Influence on 'Sirora' Pistachio Nut Quality}

\author{
Jianlu Zhang ${ }^{1}$ and Trevor Ranford ${ }^{1}$
}

AdDitional INDEX wORDs. Australia, blank nuts, damaged-shell nuts, narrow-split nuts, Pistacia vera, $r$ contour map

SUMMARY. The methodology of $r$ contour mapping was used in this study of 'Sirora' pistachio (Pistacia vera) to establish whether there are any significant relationships between fruit quality characteristics in commercial pistachio production and air temperature in the year before the harvest of the crop as measured at a nearby meteorological station. The work was done near Mildura in Australia. Blank nut percentages were found to be reduced by lower minimum temperatures in mid to late August (southern hemisphere). The percentage of narrow-split nuts was decreased by higher maximum temperatures across almost the whole growing season. Damaged-shell nuts were reduced by higher average daily minimum temperatures between $26 \mathrm{Nov}$. and $3 \mathrm{Feb}$. The technique of $r$ contour mapping is shown to have potential as a way to provide early warning of possible quality problems before harvest and as a means of generating hypotheses for future physiological studies

$\mathrm{T}$ There are few plants that are unaffected by the weather. In humankind's quest for an adequate supply of food, it is particularly important that the climatic factors affecting yield and quality are understood. Although growers can implement good management practices for pollination (Abu-Zahra and $\mathrm{Al}$ Abbadi, 2007) and irrigation (Ak and Agackesen, 2005) to maximize crop load (Boler, 1998), trees still produce different fruit or nut sizes and quality in different years. This is a result, in part, of seasonally different weather (particularly temperature) during those years. Our knowledge of the physiology and biochemistry of the plants may guide us on how to approach major climate influences (Barlow and Cumming, 1975; Beattie and Folley, 1978; Jackson and Hamer, 1980). However, it is difficult to identify important growth periods when weather can have a large influence; but, attempts have been made. For example, studies of apple (Malus domestica) have shown that

Received for publication 10 Nov. 2020. Accepted for publication 27 Jan. 2021.

Published online 13 April 2021

${ }^{1}$ Pistachio Growers' Association Inc., 3067 Murray Valley Highway, Robinvale, Victoria 3549, Australia We thank Ben Robinson for his valuable input and editing of the manuscript.

J.Z. is the corresponding author. E-mail: pgai@iinet. net.au.

This is an open access article distributed under the CC BY-NC-ND license (https://creativecommons.org/ licenses/by-nc-nd/4.0/).

https://doi.org/10.21273/HORTTECH04760-20 autumn temperatures and sunlight hours can affect the yield the following season (Beattie and Folley, 1977; Jackson et al., 1983; Lakso 1987). Kallsen (2017) used multiple regression to explore the effects of air temperature on pistachio yields. $\mathrm{He}$ used more than 10 different periods with different air temperatures to correlate aspects of weather to yield. $\mathrm{He}$ found that temperatures in the northern hemisphere from 15 Nov. to $15 \mathrm{Feb}$. greater than $18.3^{\circ} \mathrm{C}$ and during bloom from 20 Mar. to 20 Apr. greater than $26.7^{\circ} \mathrm{C}$ correlated with lower yields. Obviously, our knowledge of the response of crops to weather factors is far from complete. This is the case in pistachio (Pistacia vera).

To predict plant responses usefully in such things as fruit size, maturity date, nut quality, and so on, growers not only need to know which climatic factors are important, but also they need to know over which period(s) any specific aspect of the environment is a key driver.

A few studies describe how to find the key periods of weather that influence fruit/nut production behavior. Goldwin (1982), working with apple, used daily temperature recordings during the dormancy period through to harvest time to calculate all $r$ values (correlation coefficients) between temperature over any $2 \mathrm{~d}$ during that period and crop yield. He plotted a three-dimensional graph showing the peaks and troughs of $r$ values against different periods. $\mathrm{He}$ found that the average maximum daily temperature starting $99 \mathrm{~d}$ after full bloom over a $45-\mathrm{d}$ period and the average minimum daily temperature starting $79 \mathrm{~d}$ before full bloom over a 46-d period had major influences on yield. Data presentation in studies like this can be difficult. Threedimensional graphs show patterns of $r$ values changing, without allowing the reader to understand the $r$ values. To find the key period influencing 'Royal Gala' apple size, Zhang and Thiele (1992) created $r$ contour maps that showed the actual $r$ values. They collected and summarized data relating monthly mean maximum temperature and apple fruit size from flower bud initiation until apple harvest over an 18 -month period (171 month-combinations). They found that maximum temperature between December and January in New Zealand (equivalent to June and July in the northern hemisphere, the fruit enlargement stage) had a strong influence on 'Royal Gala' apple size.

In two-dimensional $r$ contour maps such as those presented here (see Table 1), the third dimension is provided through the use of color. The choice of color is based on the common use in geographical maps, where latitude and longitude are represented by the $x$ - and $y$-axes, and differences in altitude are denoted by different colors. For example, lower nonsignificant $r$ values are green, similar to the lower altitudes in mapping, progressing through yellow (indicating a $5 \%$ significant level of positive correlation) to brown (indicating a $1 \%$ significant level of positive correlation), equivalent to high-level altitudes in mapping. Blue indicates negative $r$ values, with light blue

\begin{tabular}{llll}
\hline $\begin{array}{l}\text { Units } \\
\begin{array}{l}\text { To convert U.S. to SI, } \\
\text { multiply by }\end{array}\end{array}$ & U.S. unit & SI unit & $\begin{array}{l}\text { To convert SI to U.S., } \\
\text { multiply by }\end{array}$ \\
\hline 0.3048 & $\mathrm{ft}$ & $\mathrm{m}$ & 3.2808 \\
2.2417 & ton $(\mathrm{s}) / \mathrm{acre}$ & $\mathrm{t} \cdot \mathrm{ha}^{-1}$ & 0.4461 \\
$\left({ }^{\circ} \mathrm{F}-32\right) \div 1.8$ & ${ }^{\circ} \mathrm{F}$ & ${ }^{\circ} \mathrm{C}$ & $\left({ }^{\circ} \mathrm{C} \times 1.8\right)+32$
\end{tabular}


Table 1. $r$ contour map for correlations between the percentages of blank nuts of pistachio assessed before harvest each year and average daily minimum temperature from the Mildura, Australia, meteorological station from April to March of the following year (equivalent to October to September in the northern hemisphere, or the whole year). Each cell represents temperature data averaged over 1 month or more. If there are filled cells to the left of a particular cell, the independent variable for that cell is the average of the minimum temperature for that month together with the data from the months to the left of the cell. In the cells, green represents no significance, yellow shows significance at $P<0.05$, and orange shows significance at $P<0.01$.

\begin{tabular}{|c|c|c|c|c|c|c|c|c|c|c|c|c|}
\hline & Apr & May & Jun & Jul & Aug & Sep & Oct & Nov & Dec & Jan & Feb & Mar \\
\hline Apr & -0.16 & -0.18 & -0.11 & -0.04 & 0.16 & 0.18 & 0.32 & 0.3 & 0.31 & 0.34 & 0.33 & 0.41 \\
\hline May & & -0.16 & -0.06 & 0.03 & 0.28 & 0.28 & 0.44 & 0.4 & 0.4 & 0.43 & 0.4 & 0.47 \\
\hline Jun & & & 0.08 & 0.19 & 0.45 & 0.43 & 0.59 & 0.53 & 0.54 & 0.53 & 0.48 & 0.54 \\
\hline Jul & & & & 0.47 & 0.65 & 0.53 & 0.73 & 0.59 & 0.57 & 0.53 & 0.47 & 0.52 \\
\hline Aug & & & & & 0.6 & 0.47 & 0.73 & 0.56 & 0.54 & 0.5 & 0.45 & 0.5 \\
\hline Sep & & & & & & 0.11 & 0.59 & 0.39 & 0.39 & 0.37 & 0.32 & 0.41 \\
\hline Oct & & & & & & & 0.6 & 0.3 & 0.3 & 0.33 & 0.29 & 0.38 \\
\hline Nov & & & & & & & & 0.02 & 0.08 & 0.19 & 0.17 & 0.28 \\
\hline Dec & & & & & & & & & 0.15 & 0.27 & 0.22 & 0.35 \\
\hline Jan & & & & & & & & & & 0.23 & 0.19 & 0.34 \\
\hline Feb & & & & & & & & & & & 0.06 & 0.33 \\
\hline Mar & & & & & & & & & & & & 0.48 \\
\hline
\end{tabular}

being the $5 \%$ significant level of negative correlation and dark blue being the $1 \%$ significant level of negative correlation (Zhang, 1993).

Although Goldwin (1982) proposed the use of daily temperature values, there are too many data from dormancy period to fruit harvest for this to be a workable technique. With more than $250 \mathrm{~d}$ and 10,000 combination, a three-dimensional graph cannot provide accurate information for each $r$ value. The technique of $r$ contour mapping provides us with the opportunity to view the correlation details over different time intervals. Zhang (1993) further explored $r$ contour mapping, focusing on daily records, but only during key periods identified using temperature data averaged over longer periods (e.g., month by month). This technique has also been used for the prediction of nut size in 'Sirora' pistachio (Zhang and Joyce, 2011).

In Australia, many aspects of pistachio production, including bud burst and nut quality, are influenced by aspects of weather, and each relationship needs to be understood separately. We have documented chill requirements (Zhang and Taylor, 2011) and heat requirements (Zhang et al., 2015). This study examined the effect of maximum and minimum air temperature over the previous 12 months on a range of nut quality disorders (the percentages of blank nuts, narrow-split nuts, and damaged-shell nuts) at harvest time over
16 years. Verification is provided by applying the models obtained to data collected in the subsequent 5 years.

\section{Materials and methods}

ESTABLISHING $R$ CONTOUR MAPS. 'Sirora' pistachio is the major cultivar used in Australian pistachio production. In comparison with 'Kerman' pistachio grown in the same orchard, the canopy is more drooping in habit. Its budbreak is about a few days earlier and harvest is about 2 weeks earlier than 'Kerman'. Although the Australia pistachio industry has good yearly records for all individual orchards and for the whole industry, this study used production data for 'Sirora' pistachio from one large orchard and linked it to an individual meteorological station. The orchard selected [Kyalite Pistachios, New South Wales, Australia (lat. $34^{\circ} 57^{\prime} \mathrm{S}$; long. $143^{\circ} 29^{\prime} \mathrm{E}$; elevation, $68 \mathrm{~m}$ ) is irrigated with low-level sprinklers. Irrigation scheduling is managed using capacitance probes (Sentek, Stepney, South Australia, Australia). During each irrigation cycle, daily water use is replaced. Application frequency and amount may be increased depending on the stage of growth and impending weather conditions. The orchard provides more than one-third of Australian pistachio production. Throughout the entire study, orchard yields averaged $2.8 \mathrm{t} \cdot \mathrm{ha}^{-1}\left(\mathrm{sD}, \mathrm{l} .5 \mathrm{t} \cdot \mathrm{ha}^{-1}\right)$. These yields are among the best achieved in
Australian orchards. There were no correlations between yield and the occurrence of any of the nut disorders. We used nut yield and pack-out assessments taken from the processing plant for harvests from 2000 to 2015 to determine percentage narrowsplit nuts and damaged-shell nuts. As a result of a severe anthracnose (Colletotrichum acutatum) infection in season 2010-11, the data from this season were not included.

Data relating to blank nuts were not obtained from the pack-out records. Although these assessments record some level of blank nuts, they underrecord the disorder because many more blank nuts remain on the trees after shaking than are collected at harvest. At Kyalite Pistachios, to help predict nut maturity, beginning about 2 months before maturity, samples of 150 nuts from 'Sirora' pistachio trees on rootstock 'Pioneer Gold I' were collected weekly during each of the 15 years of the study period (Bowring and Zhang, 2005). Fruit was cut by hand, and percentages of blank nuts recorded. For each year, the greatest percentage found was used as the percentage of blank nuts for the correlation analysis reported here.

Daily maximum and minimum temperature data from 1999 to 2015 were collected from the Bureau of Meteorology recording station (ID 076031) at Mildura, Australia (lat. $34^{\circ} 14^{\prime} \mathrm{S}$; long. $142^{\circ} 5^{\prime} \mathrm{E}$; elevation, $51 \mathrm{~m}$ ). During each 12 -month study period, the temperature data collection 
commenced in April (equivalent to October in the northern hemisphere), after harvest in the previous growing season, and continued until nut harvest began the following March (equivalent to September in the northern hemisphere). The independent variable in each correlation analysis was the mean maximum or mean minimum temperature for the period chosen (whole month to identify the best general relationship, 10-d period to focus on a finer scale, or individual day to identify most precisely the period over which the weather had the strongest impact). The dependent variable was the percentage of nuts showing the quality disorder being investigated.

In Table 1 , the months are marked as April to May (equivalent to October-November in the northern hemisphere, after harvest) and so on. The study also included the combinations of months [e.g., from April to May, April to June (equivalent to December in the northern hemisphere, the dormancy period)] and so on up until April to the following March (equivalent to September in the northern hemisphere, the harvest period), resulting in 78 relationships. When key periods were identified, averages over 10$\mathrm{d}$ periods within those key periods were calculated, and, last, daily air temperature values were used within the areas of strongest influence. Correlation coefficients were calculated using Minitab (version 17; Minitab, State College, PA) macro packages. This method was also used for the 10-d blocks and daily temperature values to refine further the definition of critical periods during the growth cycle of the plants.

Winter chill is a major factor influencing pistachio production. For enough chill accumulation, 'Sirora' pistachio trees in Australia require 59 chill portions (Zhang and Taylor, 2011). From 2000 to 2015 , the winters of 2005,2009 , and 2013 did not receive enough chill. Winter oil treatment to break dormancy or rest is used routinely in Australian orchards

VALIDATION TEST. The same pack-house data, and field assessment of percentages of blank nuts, narrowsplit nuts, and damaged-shell nuts were related to year-by-year weather data for all years from 2016 through 2020. These results were used to test the reliability of the model. During

Table 2. $r$ Contour map for correlations between the percentages of blank nuts of pistachio assessed before harvest each year and average daily minimum temperature from the Mildura, Australia, meteorological station for 10-d periods from the beginning of June to the end of November (equivalent to December to April in the northern hemisphere, late winter to fall). Each cell represents temperature data averaged over one or more 10-d period. If there are filled cells to the left of a particular cell, the independent variable for that cell is the average of the temperature data for that 10 -d period and those to its left. In the cells, green represents no significance, yellow shows significance at $P<0.05$, and orange shows significance at $P<0.01$.

\begin{tabular}{|c|c|c|c|c|c|c|c|c|c|c|c|c|c|c|c|}
\hline & $1 \mathrm{Jul}$ & $2 \mathrm{Jul}$ & $3 \mathrm{Jul}$ & 1 Aug & 2 Aug & 3 Aug & 1 Sep & $2 \mathrm{Sep}$ & 3 Sep & $10 \mathrm{ct}$ & 2 Oct & $30 \mathrm{Oct}$ & $1 \mathrm{Nov}$ & $2 \mathrm{Nov}$ & $3 \mathrm{Nov}$ \\
\hline $1 \mathrm{Jul}$ & 0.14 & 0.42 & 0.48 & 0.36 & 0.48 & 0.64 & 0.64 & 0.57 & 0.52 & 0.58 & 0.66 & 0.73 & 0.69 & 0.58 & 0.56 \\
\hline $2 \mathrm{Jul}$ & & 0.33 & 0.33 & 0.30 & 0.44 & 0.60 & 0.57 & 0.51 & 0.46 & 0.52 & 0.60 & 0.70 & 0.71 & 0.60 & 0.57 \\
\hline $3 \mathrm{Jul}$ & & & -0.02 & 0.08 & 0.33 & 0.55 & 0.56 & 0.52 & 0.44 & 0.51 & 0.61 & 0.70 & 0.69 & 0.55 & 0.50 \\
\hline 1Aug & & & & 0.10 & 0.34 & 0.58 & 0.61 & 0.52 & 0.46 & 0.53 & 0.63 & 0.72 & 0.69 & 0.58 & 0.56 \\
\hline 2 Aug & & & & & 0.44 & 0.74 & 0.66 & 0.55 & 0.47 & 0.55 & 0.67 & 0.75 & 0.71 & 0.60 & 0.57 \\
\hline 3 Aug & & & & & & 0.67 & 0.53 & 0.43 & 0.35 & 0.45 & 0.57 & 0.71 & 0.69 & 0.55 & 0.50 \\
\hline $1 \mathrm{Sep}$ & & & & & & & 0.20 & 0.14 & 0.11 & 0.24 & 0.38 & 0.59 & 0.58 & 0.44 & 0.40 \\
\hline $2 \mathrm{Sep}$ & & & & & & & & -0.03 & -0.01 & 0.22 & 0.42 & 0.61 & 0.56 & 0.36 & 0.31 \\
\hline $3 \mathrm{Sep}$ & & & & & & & & & 0.01 & 0.26 & 0.42 & 0.58 & 0.55 & 0.38 & 0.32 \\
\hline 1 Oct & & & & & & & & & & 0.51 & 0.49 & 0.60 & 0.54 & 0.36 & 0.30 \\
\hline 2 Oct & & & & & & & & & & & 0.33 & 0.54 & 0.47 & 0.29 & 0.23 \\
\hline 3 Oct & & & & & & & & & & & & 0.43 & 0.39 & 0.23 & 0.17 \\
\hline $1 \mathrm{Nov}$ & & & & & & & & & & & & & 0.26 & 0.09 & 0.02 \\
\hline $2 \mathrm{Nov}$ & & & & & & & & & & & & & & -0.02 & -0.09 \\
\hline $3 \mathrm{Nov}$ & & & & & & & & & & & & & & & -0.15 \\
\hline
\end{tabular}

Table 3. $r$ Contour map for correlations between the percentage of narrow-split nuts of pistachio at harvest and average daily maximum temperature from the Mildura, Australia, meteorological station averaged over 1 to 12 months from April of the previous year to March in the harvest year (equivalent to October-September in northern hemisphere, the whole year). Each cell represents temperature data averaged over 1 month or more. If there are filled cells to the left of a particular cell, the independent variable for that cell is the average of the minimum temperature for that month together with the data from the months to the left of the cell. In the cells, green represents no significance, cerulean shows significance at $P<0.05$, and blue shows significance at $P<0.01$.

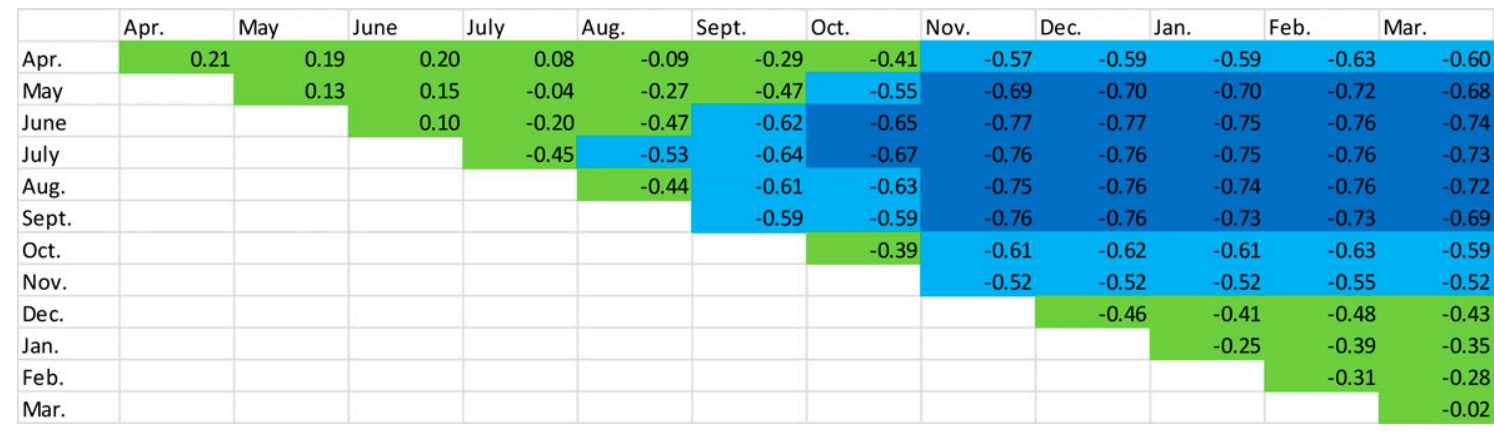


Table 4. $r$ Contour map for correlations between the percentage of damaged-shell nuts of pistachio at harvest and average daily minimum temperature from the Mildura, Australia, meteorological station averaged over 1 to 12 months (April to March of the following year, equivalent to October to September of the following year in the northern hemisphere, or the whole year). Each cell represents temperature data averaged over 1 month or more. If there are filled cells to the left of a particular cell, the independent variable for that cell is the average of the minimum temperature for that month together with the data from all the months to the left of the cell. In the cells, green represents no significance, cerulean shows significance at $P<0.05$, and blue shows significance at $P<0.01$.

\begin{tabular}{|c|c|c|c|c|c|c|c|c|c|c|c|c|}
\hline & Apr & May & Jun & Jul & Aug & Sep & Oct & Nov & Dec & Jan & Feb & Mar \\
\hline Apr & -0.42 & -0.30 & -0.20 & -0.19 & -0.21 & -0.09 & -0.18 & -0.31 & -0.44 & -0.56 & -0.54 & -0.54 \\
\hline May & & -0.07 & 0.00 & 0.01 & -0.04 & 0.09 & -0.04 & -0.20 & -0.36 & -0.52 & -0.49 & -0.47 \\
\hline Jun & & & 0.08 & 0.06 & 0.00 & 0.14 & -0.01 & -0.20 & -0.40 & -0.55 & -0.50 & -0.48 \\
\hline Jul & & & & 0.01 & -0.09 & 0.15 & -0.06 & -0.28 & -0.49 & -0.60 & -0.53 & -0.51 \\
\hline Aug & & & & & -0.13 & 0.17 & -0.07 & -0.31 & -0.53 & -0.63 & -0.56 & -0.53 \\
\hline Sep & & & & & & 0.34 & -0.02 & -0.33 & -0.58 & -0.66 & -0.56 & -0.54 \\
\hline Oct & & & & & & & -0.35 & -0.46 & -0.64 & -0.71 & -0.63 & -0.60 \\
\hline Nov & & & & & & & & -0.35 & -0.56 & -0.69 & -0.59 & -0.58 \\
\hline Dec & & & & & & & & & -0.71 & -0.78 & -0.61 & -0.57 \\
\hline Jan & & & & & & & & & & -0.53 & -0.42 & -0.40 \\
\hline Feb & & & & & & & & & & & -0.08 & -0.15 \\
\hline Mar & & & & & & & & & & & & -0.18 \\
\hline
\end{tabular}

those years, the winters of 2016 , 2018 , and 2019 did not receive sufficient chill portions at Kyalite Pistachios.

\section{Results}

Percentage of blank nuts. Blank nuts represent about 25\% of the total nut production based on nut counts, which are the data we have used. Because so many blank nuts remain on the trees after harvest, packing-shed data do not give a good estimate of the actual losses attributable to blank nuts. The production of blank nuts represents a poor use of energy, nutrition, and water during the production period, so understanding the impact of seasonal weather on this disorder is important.

Table 1 shows a contour map for $r$ values and the influence of average monthly minimum temperature on the observed percentage of blank nuts. The first set of values on the left side of each row in Table 1 are direct month-to-month correlations with the percentage of blank nuts. Elsewhere in the table, the $r$ value represents the strength of the relationship between the percentage of blank nuts and the mean minimum temperature averaged across the particular month together with all the months to its left. For example, in the first row, -0.16 is the $r$ value for the correlation between the percentage of blank nuts throughout the entire study, with the average minimum temperature in April only (equivalent to October in the northern hemisphere, directly after harvest), and -0.18 is the $r$ value for the correlation between the percentage of blank nuts and the mean minimum temperatures over April and May (equivalent to October and November in the northern hemisphere, after harvest) together. Yellow cells show $r$ values at $P \leq 0.05$ and brown cells show $r$ values at $P \leq 0.01$.

Table 1 shows that the $r$ values from June to January and as late as March (equivalent to DecemberJuly, and as late as September in the northern hemisphere, almost the whole growing season) reached significant levels. The highly significant periods were around August and again around October (equivalent to February and April in the northern hemisphere, from before budbreak to nut set) (in brown in Table 1). Thus, the study was refocused between $\mathrm{Au}$ gust and October to refine further the identification of a key period.

Table 2 shows the contour map for $r$ values of minimum temperatures between July and November (equivalent to January and May in the northern hemisphere, or from dormancy to the early nut growing period) using $10-\mathrm{d}$, rather than monthly, averages. To express date intervals, "l Jul" represents the first $10 \mathrm{~d}$ of July (equivalent to the first 10 $\mathrm{d}$ of January in the northern hemisphere, during the dormancy period), " 2 Jul" represents the second $10 \mathrm{~d}$ of July, and so on. Throughout this period, more data reached significant levels (yellow cells in Table 2). The highly significant $r$ values occurred between mid-August and late-October (equivalent to mid-February-late April in the northern hemisphere, or from the dormancy period to nut set), which therefore became the new focus period.

A new $r$ contour map was developed for 1 Aug. to 8 Nov. (equivalent to 1 Feb.-8 May in the northern hemisphere, from dormancy to the early nut growing period) using dayby-day minimum temperature data, and the peak $r$ value was 0.838 between 12 Aug. and 1 Sept. (equivalent to $12 \mathrm{Feb}$. and 1 Mar. in the northern hemisphere, or the late dormancy period). Because of the large amount of data in that table, it was not included in this article; instead, Fig. I presents the actual regression graph for that date range and shows the strength of the relationship. All points have a numerical date indicating the relevant harvest year. Most points are solid circles, but those points for 2016-20 are open circles. These five points were obtained after the calculations for the $r$ contour map and regression, and may be taken as a test of the strength of the relationship. One can see that the five points still fit into this relationship and, although the $r$ value increased from 0.838 to 0.848 at $P<0.001$, it indicates the $r$ contour map is still reliable, which then gives us confidence in the approach.

From Fig. 1, one can see that the high points $(2010,2014$, and 2017) 
were low-chill winters. The period from 12 Aug. to 1 Sept. (equivalent to $12 \mathrm{Feb}$. and 1 Mar. in the northern hemisphere, the late dormancy period) is almost the last stage of winter chill accumulation in Australia.

Percentage of Narrow-SPlit NUTs. Narrow-split nuts $(<\mathrm{l}-\mathrm{mm}$ opening, which is difficult to open without using a fingernail) represent another important quality defect in 'Sirora' pistachio. In contrast to the data presented earlier, and as shown in Table 3, the mean maximum temperature between June and November (equivalent to December and May in the northern hemisphere, from the dormancy period to the early nut growing period) was the major influence on the presence of narrowsplit nuts. Lower temperatures were associated with greater numbers of narrow-split nuts.

This range was too large to draw another $r$ contour map based on 10 $\mathrm{d}$ averages. By calculating directly, on a daily basis, from 1 May to 8 Feb. (equivalent to 1 Nov.-8 Aug. in the northern hemisphere, from the dormancy period to the early nut feeding period), the data highlight that the greater $r$ value of -0.825 was between 10 June and $13 \mathrm{Dec}$. (equivalent to 10 Dec. and 13 June in the northern hemisphere, from the dormancy period to the nut growing period). This indicates that a cooler average maximum temperature from dormancy to kernel development (10 June and 13 Dec. in Australia) had the strongest influence on narrow-split nuts, as shown in Fig. 2. Most points are solid circles, but the points for 2016-20 are not solid circles, because these five points were obtained after the calculations for the $r$ contour map and regression. The point corresponding to 2019 was an outlier, but the other four points are consistent with the model. The overall $r$ value at -0.644 $(P=0.002)$ is at an acceptable level.

Percentage of Damaged-Shell NUTS. Damaged-shell nuts represent another form of poor-quality nut, probably identical to the "damaged by other means" disorder (Fig. 3) (Fabbri et al., 1998). Table 4 shows that the minimum temperatures between December and January (equivalent to June and July in the northern hemisphere, the nut feeding stage) were an important factor influencing the percentage of damaged-shell

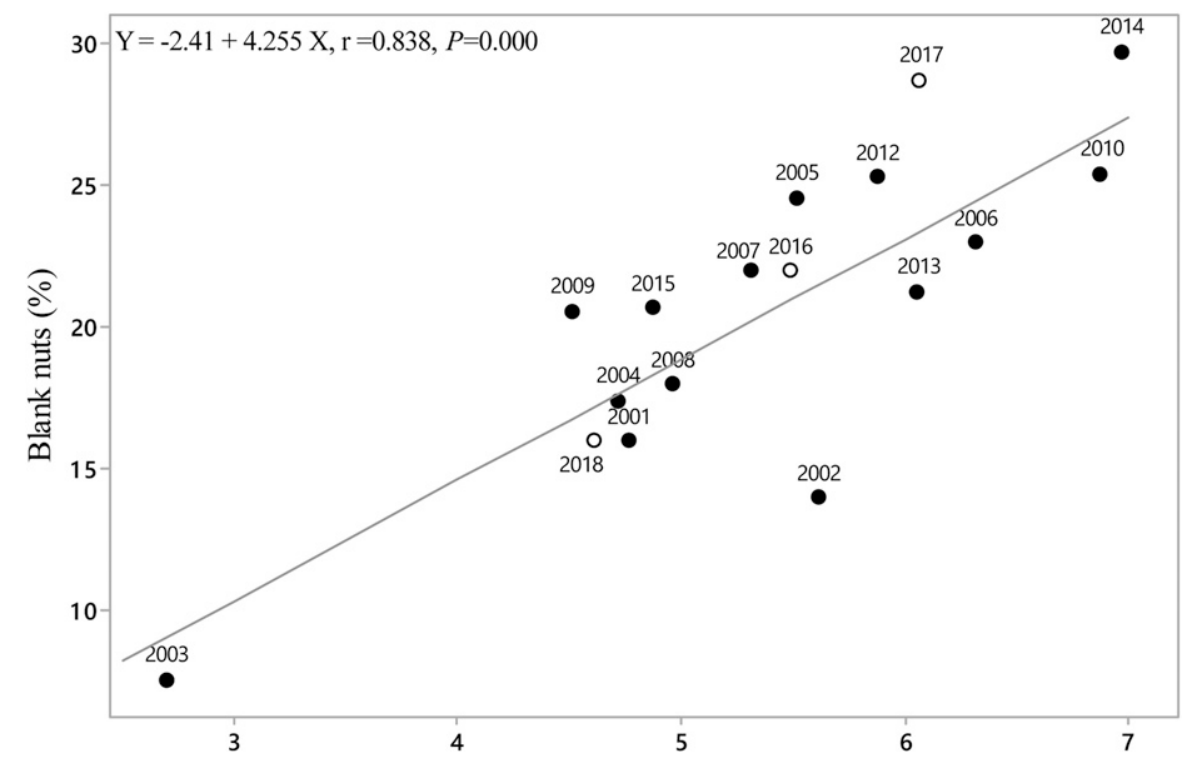

Average minimum temperature $\left({ }^{\circ} \mathrm{C}\right)$ from 12 Aug. to 1 Sept.

Fig. 1. Relationship between the percentage of blank nuts of pistachio and average minimum temperature between 12 Aug. and 1 Sept. (equivalent to February to March in the northern hemisphere, the late dormant period). Here the solid points are used for model establishment whereas the circles highlight new data placed into the existing model. $\left(1.8 \times{ }^{\circ} \mathrm{C}\right)+32={ }^{\circ} \mathrm{F}$.



Average maximum temperature $\left({ }^{\circ} \mathrm{C}\right)$ from 10 June to $13 \mathrm{Dec}$.

Fig. 2. Relationship between the percentage of narrow-split nuts of pistachio and average maximum temperature between 10 June and 13 Dec. (December to June in the northern hemisphere, late dormancy to shell hardening). Here the solid points are used for model establishment whereas the circles highlight new data placed into the existing model. $\left(1.8 \times{ }^{\circ} \mathrm{C}\right)+32={ }^{\circ} \mathrm{F}$.

nuts. The correlation between percentage of damaged-shell nuts and minimum temperature was negative. Table 5 shows a contour map for $r$ values of minimum temperatures between November and February (equivalent to May and August in the northern hemisphere, the nut 
growing period) using 10-d averages. The very significant $r$ values were between December and February. This became the new focus period.

The greatest $r$ value for the correlation between the average minimum temperature and the percentage of damaged-shell nuts was 0.785 for the period $26 \mathrm{Nov}$. to $3 \mathrm{Feb}$. (equivalent to late May to early August in the northern hemisphere, the nut growing period), as shown in Fig. 4. To assist in understanding the graph better, all points have a numerical date showing the relevant harvest year. Most points are solid circles, but the points for 2016-20 are not solid circles because these five points were fitted values from the regression.
Four of the five points were good fits to the regression, but 2019 was an outlier. Including all points changed the $r$ value from -0.785 to -0.659 $(P=0.002)$.

\section{Discussion}

In this study, we showed that $r$ contour maps are another tool to view and help understand weather influences mediated by maximum or minimum daily temperatures. If a critical period in the development of a disorder can be identified, then it may be possible to use changes in management to minimize risk, or to develop hypotheses regarding physiological "drivers" that can, in turn, be managed in the orchard.
We emphasize that the $r$ contour map procedure should be used with caution. In our study, during the first round of using this approach, a relationship between dark stain (another nut disorder with no known pathogen, recognized in Australia) and a temperature variable was found. However, in subsequent seasons, this relationship was not present. That relationship may have been just a calculation coincidence among such a large number of calculations.

Are the relationships consistent if the dates and/or period drift a little? Our answer is that there was no real or significant change from year to year. For example, for blank nuts, the important dates were between 12

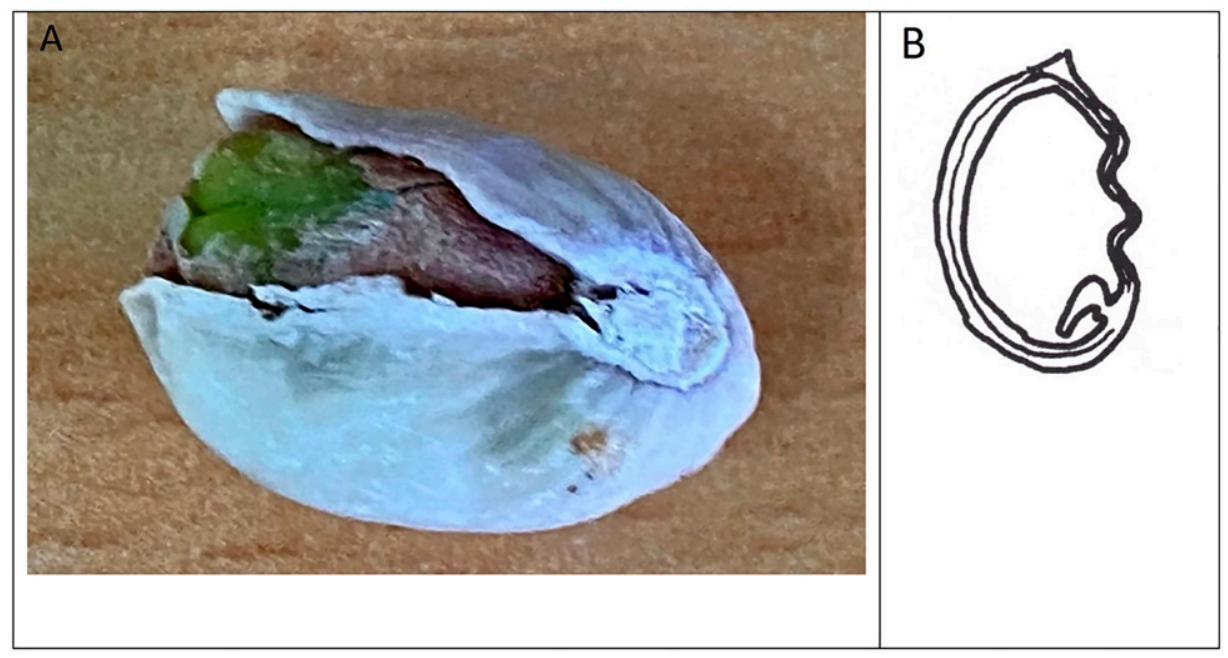

Fig. 3. Damaged-shell pistachio nuts. (A) The photograph kindly provided by Dr. Subashini Abeysinghe shows the shell margin has broken irregularly. (B) A schematic diagram from Fabbri et al. (1998).

Table 5. $r$ Contour map for correlations between the percentages of damaged-shell nuts of pistachio at harvest and average daily minimum temperature from the Mildura, Australia, meteorological station for 10-d periods from November to February (equivalent to May to August in the northern hemisphere, the nut growing period). Each cell represents temperature data averaged over one or more 10 -d period. If there are filled cells to the left of a particular cell, the independent variable for that cell is the average of the minimum temperature for that $10-\mathrm{d}$ period together with the data from all the periods to the left of the cell. In the cells, green represents no significance, cerulean shows significance at $P<0.05$, and blue shows significance at $P<0.01$.

\begin{tabular}{|c|c|c|c|c|c|c|c|c|c|c|c|c|}
\hline & $1 \mathrm{Nov}$ & $2 \mathrm{Nov}$ & $3 \mathrm{Nov}$ & $1 \mathrm{Dec}$ & $2 \mathrm{Dec}$ & $3 \mathrm{Dec}$ & $1 \mathrm{Jan}$ & 2 Jan & 3 Jan & $1 \mathrm{Feb}$ & $2 \mathrm{Feb}$ & 3 Feb \\
\hline $1 \mathrm{Nov}$ & -0.23 & -0.40 & -0.35 & -0.48 & -0.49 & -0.56 & -0.59 & -0.65 & -0.69 & -0.67 & -0.68 & -0.58 \\
\hline $2 \mathrm{Nov}$ & & -0.41 & -0.33 & -0.45 & -0.46 & -0.55 & -0.59 & -0.66 & -0.71 & -0.69 & -0.69 & -0.59 \\
\hline $3 \mathrm{Nov}$ & & & -0.01 & -0.28 & -0.32 & -0.51 & -0.56 & -0.61 & -0.69 & -0.67 & -0.67 & -0.54 \\
\hline $1 \mathrm{Dec}$ & & & & -0.47 & -0.49 & -0.70 & -0.71 & -0.72 & -0.77 & -0.71 & -0.71 & -0.59 \\
\hline $2 \mathrm{Dec}$ & & & & & -0.27 & -0.56 & -0.63 & -0.65 & -0.67 & -0.62 & -0.65 & -0.52 \\
\hline $3 \mathrm{Dec}$ & & & & & & -0.56 & -0.67 & -0.62 & -0.65 & -0.59 & -0.62 & -0.48 \\
\hline 1 Jan & & & & & & & -0.50 & -0.48 & -0.53 & -0.50 & -0.54 & -0.40 \\
\hline 2 Jan & & & & & & & & -0.26 & -0.37 & -0.35 & -0.41 & -0.27 \\
\hline 3 Jan & & & & & & & & & -0.32 & -0.33 & -0.41 & -0.23 \\
\hline 1 Feb & & & & & & & & & & -0.20 & -0.23 & -0.06 \\
\hline 2 Feb & & & & & & & & & & & -0.12 & 0.11 \\
\hline $3 \mathrm{Feb}$ & & & & & & & & & & & & 0.26 \\
\hline
\end{tabular}




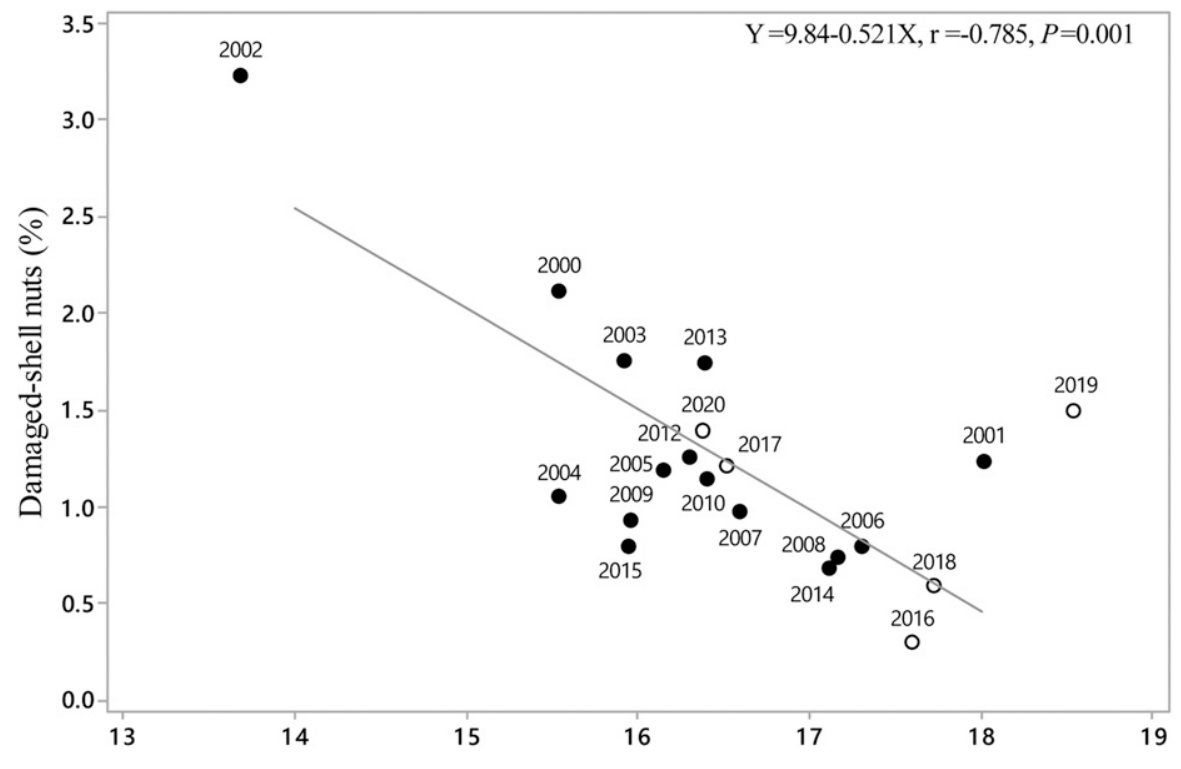

Average minimum temperature $\left({ }^{\circ} \mathrm{C}\right)$ from 26 Nov. to 3 Feb.

Fig. 4. Relationship between the percentage of damaged-shell nuts of pistachio and average minimum temperature between 26 Nov. and 3 Feb. (May to August in the northern hemisphere, early nut fill). Here the solid points are used for model establishment whereas the circles highlight new data placed into the existing model. $\left(1.8 \times{ }^{\circ} \mathrm{C}\right)+32={ }^{\circ} \mathrm{F}$.

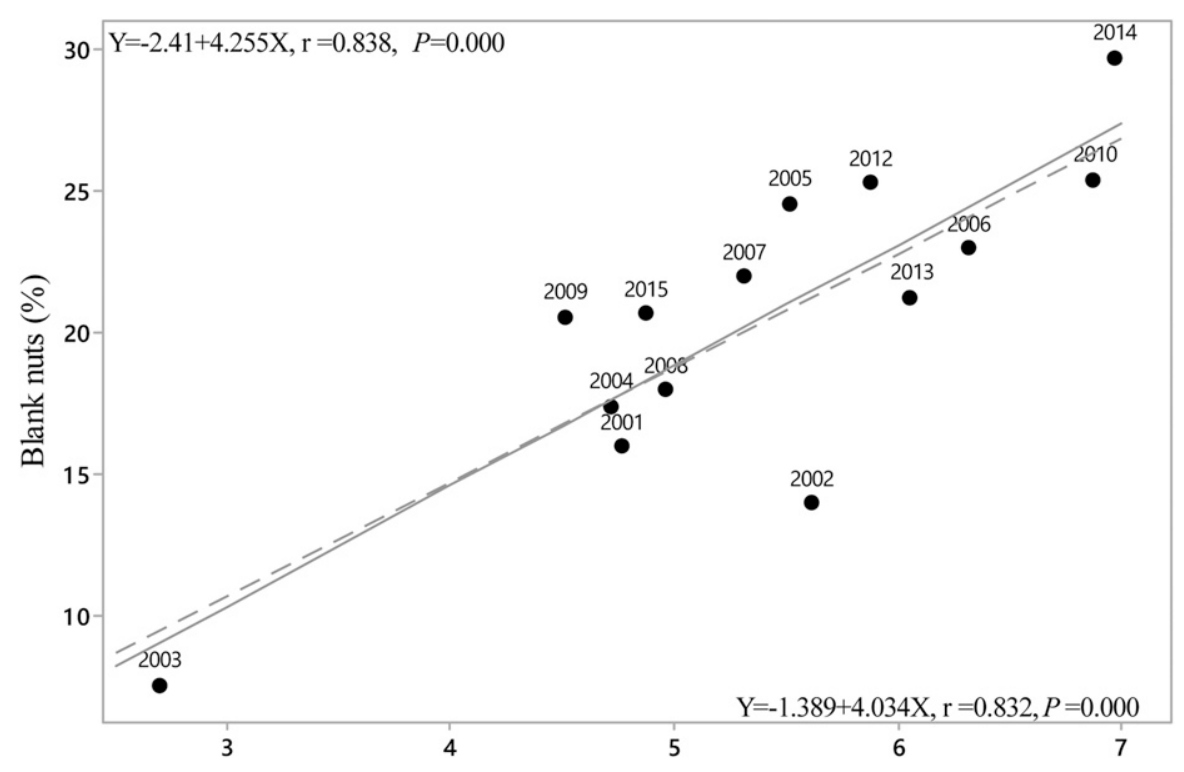

Average minimum temperature $\left({ }^{\circ} \mathrm{C}\right)$ from 12 Aug. to 1 Sept.

Fig. 5. Relationship between the percentage of blank nuts of pistachio and average minimum temperature between 12 Aug. and 1 Sept. solid line or between 13 Aug. and 1 Sept. dashed line. (February-March in the northern hemisphere, the late dormant period $) .\left(1.8 \times{ }^{\circ} \mathrm{C}\right)+32={ }^{\circ} \mathrm{F}$.

Aug. and 1 Sept. (equivalent to 12 Feb. and 1 Mar. in the northern hemisphere, the late stage for chill requirement). Can it be $1 \mathrm{~d}$ earlier or $1 \mathrm{~d}$ later? It is possible. From $12 \mathrm{Aug}$. to 1 Sept., a period of $21 \mathrm{~d}$, the calculations for the average temperatures of those $21 \mathrm{~d}$ are shown. If you add or subtract one more day before or after this period, the new average is not too different from the original average. Using the new average to correlate the percentage of blank nuts, the $r$ value is very similar. For example, the $r$ value from 13 Aug. to 1 Sept. was 0.832 . Figure 5 shows two regression lines for these two periods and, although the slopes are a little different, they are still in the useful range. The two lines do not provide predictions that are too different. The key point is that this tool allows us to find the key area(s). These period zones are useful for increasing our physiological understanding and for providing the opportunity to make sound predictions. Of course, if there is a series of useful relationships, users usually select the relationship with the greatest $r$ value.

As noted earlier, potential physiological relationships are possible findings from the $r$ contour map calculations. For instance, with blank nuts, many researchers have focused on parthenocarpy (Polito, 1999; Shuraki and Sedgley, 1996) or postfertilization embryo abortion (Crane, 1975). However, the incidence of the disorder varies from year to year (Polito, 1999; Spann et al., 2009), but within the same time frames within those different years. This suggests that weather for each year may have an influence on the percentage of blank nuts. In our study, the key period was identified as middle to late August (equivalent to middle to late February in the northern hemisphere). This is within the chill period, rather than during the growing season. Cold temperature is important because if there is not enough chill, it may lead to poor flower bud development. Although flower bud initiation and development are nearly a whole year-round process, the three-carpellate pistil is developed in late March in California (equivalent to late September in the southern hemisphere) (Takeda et al., 1979). The ovule develops from the functional carpel and this is the part that forms the kernel. Unfavorable conditions at this time may lead to poor flower development and may increase poor kernel development (i.e., blank nuts). In work with apple, Goldwin (1982) and Zhang (1993) reported that low temperatures before budbreak may increase both yield and fruit size. 
For a low percentage of narrowsplit nuts, the key period was from 10 June to 13 Dec. (equivalent to 10 Dec. to 13 June in the northern hemisphere, from dormancy to the start of kernel development). Warm weather may lead to kernels developing into larger kernels; thus, less narrow-split nuts develop. Also, warm temperatures during the dormancy period may increase blank nuts, which may fill partially and develop into narrow-split nuts.

The percentage of damagedshell nuts at harvest in Australia is about $0.5 \%$ to $1.5 \%$. This deformity becomes microscopically visible in California in May (Metheney et al., 1995), and usually becomes obvious to the naked eye between early June and early August in California (Fabbri et al., 1998). Thus, the initial development of this disorder may correspond to the period from $26 \mathrm{Nov}$. to $3 \mathrm{Feb}$. (equivalent to 26 May to 3 Aug. in the northern hemisphere), the period in Australia that we have identified as being important. This period is from shell hardening to preharvest. Fabbri et al. (1998) showed that a heavy crop may result in more damage by other means. Our study shows that low minimum temperatures during this period may also increase this damage.

\section{Conclusions}

The technique of $r$ contour mapping has not been widely used in horticulture in recent years. We believe it has great potential to help develop an understanding of those aspects of the weather that may impact elements of pistachio production or quality, and when these effects might be exerted. This study used readily available meteorological data, and information that can be obtained from the processing plant or from data collected in the orchard, and has shown its potential for helping acquire an understanding of the occurrence of three nut disorders/defects of 'Sirora' pistachio in Australia. Its usefulness could be assessed relatively simply in other geographic situations and with different cultivars. In turn, the results might suggest follow-up physiological or horticultural work when sufficient research and development resources are available.

\section{Literature cited}

Abu-Zahra, T.R. and A.A. Al-Abbadi. 2007. Effects of artificial pollination on pistachio (Pistacia vera L.) fruit cropping. J. Plant Sci. 2:228-232, doi: 10.3923/ jps.2007.228.232.

Ak, B.E. and N. Agackesen. 2005. Effects of soil type and irrigation on yield and quality of 'Kirmizi' pistachio cultivar. Options Mediterr. Ser. A: Semin. Mediterr. 63:239-245.

Barlow, H.W.B. and I.G. Cumming. 1975. Effect of early summer weather on the yield of Lane's Price Albert apple, p. 44-47. In: H.C. Pereira (ed.). Climate and the orchard. Commonwealth of the Agricultural Bureau, Wallingford, UK.

Beattie, B.B. and R.R.W. Folley. 1977. Production variability in apple crops. Scientia Hort. 6:271-279, doi: 10.1016/ 0304-4238(77)90084-X.

Beattie, B.B. and R.R.W. Folley. 1978. Production variability in apple crops: II. The long term behaviour of the English crop. Scientia Hort. 8:325-332, doi: 10.1016/0304-4238(78)90054-7.

Boler, K. 1998. Effects of fruit bud thinning and pruning on alternate bearing and nut quality of pistachio (Pistacia vera $\mathrm{L}$.). Acta Hort. 470:507-509, doi: 10.17660/ ActaHortic.1998.470.71.

Bowring, A. and J. Zhang. 2005. Pistachio nut maturity and its prediction. Austral. Nutgrower 19(2):16-18.

Crane, J.C. 1975. The role of seed abortion and parthenocarpy in the production of blank pistachio nuts as affected by rootstock. J. Amer. Soc. Hort. Sci. 100:267-270.

Fabbri, A., L. Ferguson, and V.S. Polito. 1998. Crop load related deformity of developing Pistacia vera cv 'Kerman' nuts. Scientia Hort. 77:219-234, doi: 10.1016/ S0304-4238(98)00155-1.

Goldwin, G.K. 1982. A technique for studying the association between components of the weather and horticultural parameters. Scientia Hort. 16:101-107, doi: 10.1016/0304-4238(82)90080-2.

Jackson, J.E. and P.J.C. Hamer. 1980. The causes of year-to-year variation in the average yield of Cox's Orange Pippin apple in England. J. Hort. Sci. 55:149156, doi: 10.1080/00221589.1980. 11514917.

Jackson, J.E., P.J.C. Hamer, and M.F. Wickenden. 1983. Effects of early spring temperatures on the set of fruits of Cox's Orange Pippin apple and year-to-year var- iation in its yields. Acta Hort. 139:75-82, doi: 10.17660/ActaHortic.1983.139.10.

Kallsen, C.E. 2017. Temperature-related variables associated with yield of 'Kerman' pistachio in the San Joaquin valley of California. HortScience 52:598-605, doi: 10.21273/HORTSCI11775-17.

Lakso, A.N. 1987. The importance of climate and microclimate to yield and quality in horticultural crops: Agrometeorology. 2nd Intl. Cesena Agr. Conf., Cesena, Italy, 8-9 Oct. 1987. p. 287-298.

Metheney, P., L. Baughn, and L. Ferguson. 1995. Crop load related deformity of developing Pistacia vera cv 'Kerman' nuts. Acta Hort. 419:79-84, doi: 10.17660/ ActaHortic.1995.419.11.

Polito, V.S. 1999. Seedlessness and parthenocarpy in Pistacia vera L. (Anacardiaceae): Temporal changes in patterns of vascular transport to ovules. Ann. Bot. 83:363-368, doi: 10.1006/anbo.1998.0830.

Shuraki, Y.D. and M. Sedgley. 1996. Fruit development of Pistacia vera (Anacardiaceae) in relation to embryo abortion and abnormalities at maturity. Austral. J. Bot. 44:35-45, doi: 10.1071/bt9960035.

Spann, T.M., R.H. Beede, and T.M. DeJong. 2009. Contributions of shortand long-shoots to yield of 'Kerman' pistachio (Pistacia vera L.). Scientia Hort. 121:495-500, doi: 10.1016/j.scienta.2009. 02.029 .

Takeda, F., J.C. Crane, and J. Lin. 1979 Pistillate flower bud development in pistachio. J. Amer. Soc. Hort. Sci. 104:229232.

Zhang, J. 1993. Apple tree system research. Lincoln Univ., Canterbury, New Zealand, PhD Diss.

Zhang, J. and C. Joyce. 2011. A study on climate factors on 'Sirora' pistachio nut size. Acta Hort. 912:129-135, doi: 10.17660/ ActaHortic.2011.912.18.

Zhang, J., T. Ranford, and C. Taylor. 2015. Heat model for pistachio bloom and harvest. Scientia Hort. 186:47-53, doi: 10.1016/j.scienta.2015.02.005.

Zhang, J. and C. Taylor. 2011. The dynamic model provides the best description of the chill process on 'Sirora' pistachio trees in Australia. HortScience 46:420-425, doi: 10.21273/HORTSCI.46.3.420.

Zhang, J. and G. Thiele. 1992. The dynamic apple tree system: Pomological and climatic relationships. Acta Hort. 313:107-114, doi: 10.17660/ActaHortic.1992.313.12. 